\title{
Building Rehabilitation with Dry and Wet Systems - Embodied Water Comparison
}

\author{
Mónica Macieira and Paulo Mendonça \\ Lab2PT, Architecture School of the University of Minho, Guimarães, Portugal
}

\begin{abstract}
Fresh water is a scarce resource. Its availability, essential for life, is being conditioned by several menaces, mostly from human origin. Studies on water saving strategies in building construction and what procedures should be adopted for its efficient use can respond to part of these problems, taking into account the relevance of construction activities, responsible for almost $40 \%$ of the overall environmental impact in Europe. Buildings rehabilitation assumes an important role in the construction activities of many European countries. The aim of this paper is to compare the water demand between dry and wet construction systems used in interior partition wall technologies existing in south European climates, specifically on Portuguese territory. This paper focus on the advantages of the dry and lightweight partition walls and it is expected that it may contribute for the reduction of water use in the construction industry. The evolution of interior partition walls, namely by its weight and embodied water analysis, is presented and discussed. Apart from the conclusion that dry construction systems, used in the rehabilitation of existing buildings, can contribute to a significant reduction of water demand, this analysis intends to also reveal on how much these systems can reduce other environmental impact indicators in relation to the wet conventional solutions. Dry construction strategies allows saving material and energetic resources, increasing flexibility and reducing wastes, what constitutes a relevant response to the growing concerns over environmental issues and incertitude on economic development.
\end{abstract}

\section{Water use in the construction industry}

Until 2050 it is expected a world population growth, mostly in cities of poor and under development countries. This fact will contribute to the increase of environmental pollution and to resources management problems. However, in the developed countries, the population is decreasing and policies are focused on a significant decrease on the pollutant emissions. Knowing that building construction is responsible for a significant percentage of the world consumption of fossil fuels and the emissions of greenhouse effect gases, it doesn't make sense to continue investing in new construction with so many buildings unoccupied or sub occupied. The rehabilitation of buildings has assumed an important role in the construction activities panorama of developed countries. According to published estimations, this activity represents in Europe about $45 \%$ of the total volume of investment [1-3]. Building rehabilitation will therefore be a preponderant factor to achieve sustainability.

Although the demand for water consumption has increased significantly over the last century, the infrastructure capacity to harvest adequate water to serve the Earth's growing population has not grown accordingly, and in many parts of the world, water scarcity is becoming a critical issue. In addition to the daily operation of buildings, water is used in the production of building materials.
In Europe, the construction industry is one of the sectors that consume more fresh water [4]. Water consumption practically accompanies the entire lifecycle of a building material, ranging from the extraction of raw material to the demolition phase at the end of building's life cycle.

The building's water consumption management can be realized at three levels: (1) selection of materials and components with low embodied water; (2) selection of more efficient sanitary appliances and devices; (3) provide rainwater harvesting and water reuse solutions.

Table 1. Water used in an office building during its life cycle of 50 years [5].

\begin{tabular}{lccc}
\hline & \multicolumn{3}{c}{ Building life cycle phases } \\
\cline { 2 - 4 } Resource & Construction & Use & Deconstruction \\
\hline Water $\left(\mathrm{m}^{3}\right)$ & 3.000 & 228.000 & 0 \\
\hline
\end{tabular}

There are few studies about water consumptions in buildings during its complete useful life. One available case study corresponds to an office building in Finland, with a gross area of $15.600 \mathrm{~m} 2$, constituted by three towers with five floors each. According to Junnila [5], this building had its water consumption distributed over the different life cycles phases as indicated on Table 1 .

At Table 1 it can be seen that during the building use phase occur the largest consumption, corresponding to 
approximately $99 \%$ of the total water used. Residential buildings present consumptions at the same or higher order of magnitude [5]. However, even if corresponding to just $1 \%$ of the overall number, the water consumption during the construction phase is still of 192 litre per square meter of gross area, which gives a notion of the significant water demand during the construction phase.

For the use phase is usually considered a time period of fifty years, while the construction phase has a significantly lower period of about one year. Thereby, dividing the amount of water used during the use period by fifty, corresponding to the time which it was used, a value of 4 $560 \mathrm{~m} 3$ / year was obtained.

\section{Dry construction}

\subsection{Contribute to the reduction of water use}

With an increasing fresh water scarcity it is necessary to review the currently adopted construction systems. For example, the construction based on concrete mortars, generates additional water waste on the construction sites. Water consumption in masonry wall systems uses approximately 500 litres per square meter of gross area, much more than in dry systems as can be verified at the following topics.

\subsection{Advantages for buildings rehabilitation and consequent environmental impact reduction}

Construction and mainly the housing sector consume big quantities of materials, what result on big quantities of waste according to Mateus et al [6]. Therefore for an efficient construction system it is necessary to use prefabricated elements that facilitate assembling and disassembling.

The growing use of dry construction systems in the building sector is due to the many advantages of these systems, primarily their short construction time, economy, superior building functional performance when compared to masonry and concrete systems with the same thickness [7]. Dry systems allow achieving solutions that are: lighter, flexible, quick and easy assembled, don't require much available space on site, and are easily transportable to construction site - important aspects to safeguard on rehabilitation interventions.

Assuring comfort and energy efficiency during use phase is one important goal for sustainable construction. According to Friedman [8] such aim can be accomplished through, among other aspects, the rethink of indoor space, with increased flexibility.

\subsection{Lightness}

Dry construction systems can be added to existing buildings in order to improve specific properties, an aspect that is especially important for infill development tasks (extra storeys, expansion, extensions) and alterations. The low weight of dry construction systems means that loadbearing components can be sized more economically than would be the case with a fitting out scheme involving masonry and concrete. A clear reduction in mass and at the same time better sound and thermal insulation properties are readily achievable in wall systems (partitions, external walls, facades).

\subsection{Flexibility.}

A great portion of housing designs are not flexible in use and therefore they are not adjustable to the constant updating of life styles and variations on the composition of the households. The conventional practice uses heavyweight and static partition walls and therefore it is difficult to rethink the use of the indoor spaces. This problem reveals to be especially important in the refurbishment phase of existing buildings, but also when new buildings are designed.

According to Tichelmann \& Pfau [9] these building elements were underestimated in the past. They also perspective that the vast majority of buildings erected between 1950 and 1995 will become unusable in the long term and will become increasingly difficult to let or sell. The small-format interior layouts acceptable in those days are no longer popular with actual users and buyers. Changing room sizes means an expensive intervention in the building.

The use of dry systems in lightweight construction, optimized for their particular functions, is generally associated with a gain in floor space and greater flexibility of usage - their intrinsic properties which were underestimated in the past.

Flexibility of housing spaces can increase the life time of the building, extending materials life-cycle [10]. Flexibility can be achieved through neutral and polyvalent spaces passive flexibility - or through mobile elements that allow the transformation of the housing unit - active flexibility. The second strategy can produce daily, seasonal or annual transformations of the housing unit that increase its adaptability to the user and its changeable needs. This allows saving energy and resources, since people can use their home during larger periods of time and in a more adequate way to seasonal climate variations.

Innovation in building technology and products should be conducted to increase flexibility. One of these innovations is the distinction between the structural elements and the other elements of a building [11]. A reduction in the use of load-bearing interior partitions and increase in the number of pre-manufactured components provide the opportunity for greater choice and adaptability in design and construction [9].

\section{Case study}

\subsection{Water consumption of interior partition wall systems}

Interior partition walls are thin elements built to divide the indoor space into rooms or other compartments. The importance of these building elements is reflected in the global construction cost, estimated by Köning et al [12] to be around fifteen percent in office and administration buildings of European countries. In the non-loadbearing group of technologies used on the buildings construction, 
these represent $41 \%$ of the environmental impacts, as can be seen on Figure 1.

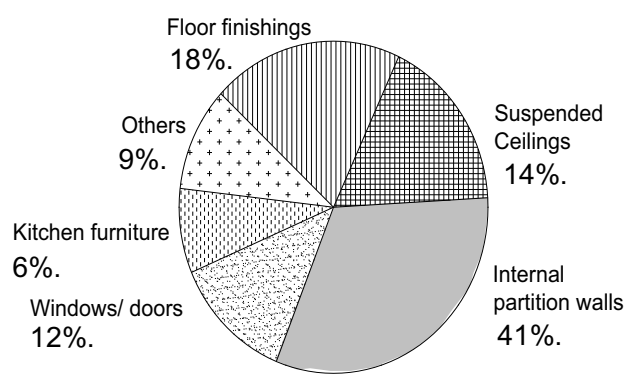

Figure 1. Environmental impacts from materials use on non-load bearing construction elements of a typical house over 60 years (adapted from Addis and Schouten [11]).

Generally, partition walls are non-load bearing. In terms of structural resistance, these elements need only to be strong enough to support themselves under normal conditions of service. In general, lightweight solutions present less embodied energy, less energy costs with transport to the building site and can be designed with smaller assembly fittings [13].

Many of the commonly used materials for interior partition walls use water as a resource for their manufacture. The following table lists some materials commonly used in construction of interior partition walls, with the corresponding amount of water demand in its manufacture according to their weight. It presents the amount of water which will have its quality drastically reduced as a result of the production process. The water recycling or purification was not taken into consideration.

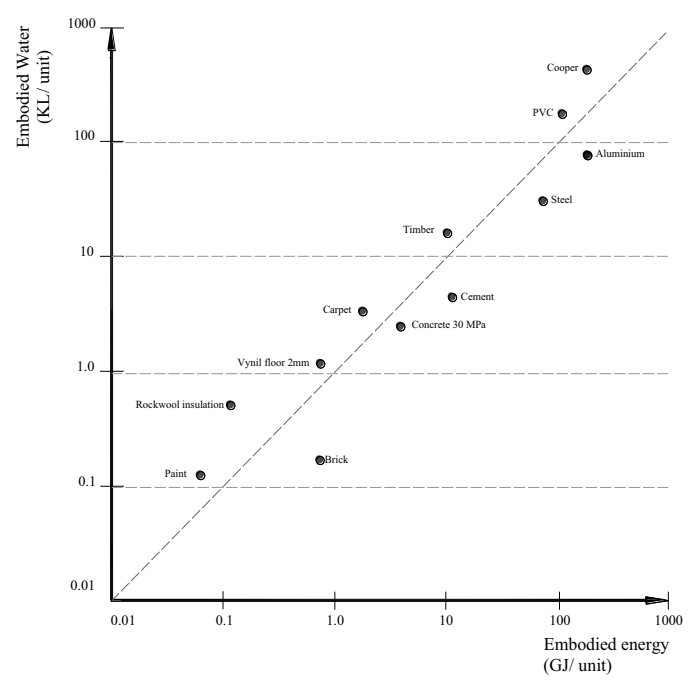

Figure 2. Embodied Energy and Embodied Water (adapted from Graham et al [14] and Vassig, Ozer and Spiegelhalter [15]).

The analysis of Table 2 makes possible to conclude that the careful selection of materials on the design phase is important for the water consumption reduction strategies on building construction. Materials such as galvanized steel consume too much water in its manufacturing process (3400 litres $/ \mathrm{kg}$ ). Moreover, the production of hemp fibres and straw presents a null use of water.
In European Palaeolithic period, the use of animal skins supported by large bones or wooden poles to build interior dividing walls in caves constituted an important innovation for future developments of exterior artificial dwellings, where the structural supporting element is independent from the covering layer [19].

Table 2. Water demand on the production phase of materials in function of their weight.

\begin{tabular}{|c|c|}
\hline Material & $\begin{array}{l}\text { Water demand } \\
\text { (litres/kg) }\end{array}$ \\
\hline Galvanized steel & 0,07 \\
\hline Local pine wood $* *$ & 4,2 \\
\hline Rockwool** & 32,0 \\
\hline Ceramic solid brick $* *$ & 1,9 \\
\hline Ceramic hollow brick** & 1,4 \\
\hline Polyvinylchloride sheet** & 511,9 \\
\hline Mortar** & 3,3 \\
\hline Plasterboard* & 0,2 \\
\hline Cork* & 25,0 \\
\hline Cellulose (loose fill 100\% recycled) $* *$ & 21,0 \\
\hline $\begin{array}{c}\text { Recycled textiles } \\
\text { (matting glued with polyester)* }^{*}\end{array}$ & 6,0 \\
\hline Polyurethane foam(PUR)** & 3,5 \\
\hline $\begin{array}{l}\text { Polyvinylchloride coated Polyester } \\
\text { membrane } * * *\end{array}$ & 1,4 \\
\hline Straw/ reed* & 0,0 \\
\hline Canes/reed* & 0,0 \\
\hline Plaster with sand** & 0,2 \\
\hline
\end{tabular}

By analysing the evolution of internal partition walls, shown at Figure 3, it is possible to verify that an initial tendency for dry and lightweight solutions evolved to wet and heavyweight solutions. However, nowadays it can be verified a tendency to the return of dry and lightweight solutions that can include easier construction/deconstruction design principles.

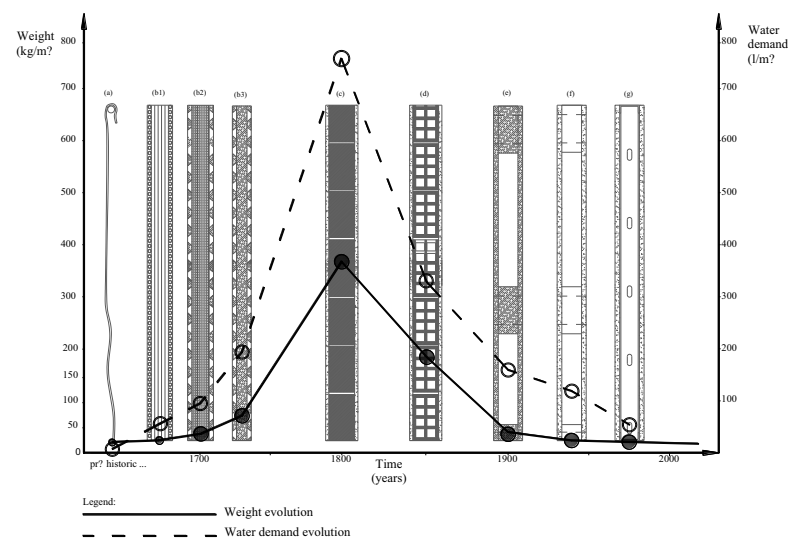

Figure 3. Evolution of weight and water demand on Mediterranean partition systems: (a) animal skin coating vegetable poles or bones; (b1) mat canes filled with reed; (b2) Wattle and daub filled with straw; (b3) wattle and daub with planks; (c) Solid Brick; (d) Hollow Brick; (e) Wooden board with timber frame; (f) Plasterboard panel with timber frame; (g) Plasterboard panel with light gauge steel frames. Scheme adapted from Mendonça and Macieira [20].

3.2 Mediterranean climate - interior partition walls 
This study takes as reference the constructive solutions of existing dividing walls in Mediterranean countries, and specifically in Portugal.

The most common solutions that can be considered as vernacular [21] are: sun-dried blocks of soil (adobe) characteristics of clay-rich zones, essentially in the south regions of Alentejo and Algarve, and the wattle and daub (Figure 4(c)) widespread through all the country, called as "tabique" (in all Portugal) and as "taipa de fasquio", (in the north region of Minho). This last one is made up of wooden planks placed vertically or in diagonal, over which are placed horizontally small strips of trapezoidal section, in which is adhered the mortar. Other solution combines timber frame filled with canes/reed. However, due to the loss of tradition in the techniques employed and consequent rising cost of hand labour, these solutions gave way to other wall types, such as the massive brick (Figure 3(c)), which later derived to the hollow brick wall (Figure 4(d)).

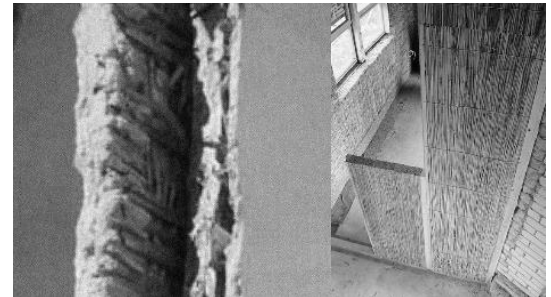

(a)

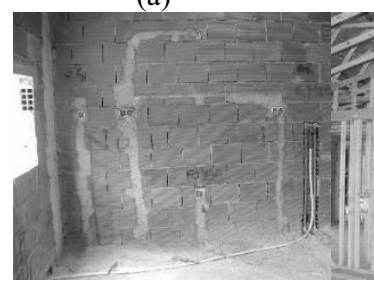

(d)
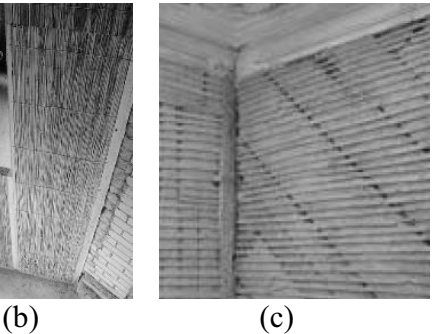

(c)
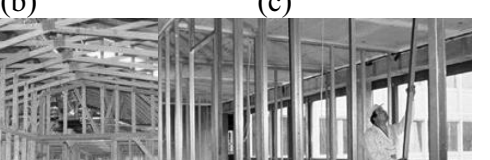
(1)

(e)
Figure 4. Non-loadbearing partitions walls in Portugal: (a) Mat canes in Lagos, Portugal; (b) wood frame filled with reed/straw; (c) Wattle and daub partition in Guimarães, Portugal; (d) Hollow brick; (e). Timber board with wood frame; (f) Plasterboard with light steel gauge frame.

The use of ceramic hollow brick in non-structural masonry became increasingly common, either by economic as well as ease of implementation reasons. With thicknesses, without finishing plaster, varying between 7 and $22 \mathrm{~cm}$, but more frequently with $11 \mathrm{~cm}$ in interior walls, this system became the preferred solution and still remains in present times. Even if new and more efficient solutions are appearing in the market, most of them cannot compete with hollow brick, not only for the economic cost, but also due to the conservative mentality of the diverse agents present on the construction sector.

One exception is a solution that has been experiencing a great development since the 70's, the plasterboard panel. First it had a timber structure filled with a honeycomb cardboard in which were fixed the plasterboard plates (Figure 4(e)). Later, around the 90's, the wood structure was replaced by light steel gauge frames (Figure 4(f)). This type of partitions can be built with $51 \times 76 \mathrm{~mm}$ or $51 \times 100 \mathrm{~mm}$ studs normally spaced between 400 to $600 \mathrm{~mm}$, depending on the type and thickness of the wall finishing used.

\section{Embodied water and environmental assessment}

The environmental impact assessment of an internal partition wall solution can be made through several indicators, such as: the Embodied Energy (EE); the Global Warming Potential (GWP), the Acidification Potential (AP), the Chemical Oxygen Depletion (COD), the Photochemical Ozone Creation Potential (POCP), the Wastes generated in production process, the Coefficient of Heat Transmission [and the Embodied Water (EW).
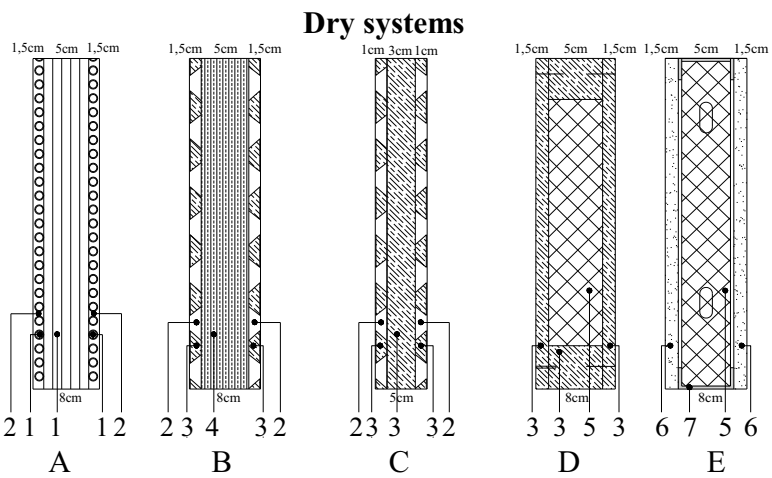

Figure 5. Transversal sections of dry interior partition wall systems analysed. Legend: 1. Canes/reed; 2 . Plaster with sand; 3. Local pine wood; 4. Straw/ reed; 5. Rock wool; 6. Carton plasterboard; 7. Light gauge steel frame; and 12. PVC coated Polyester membrane.
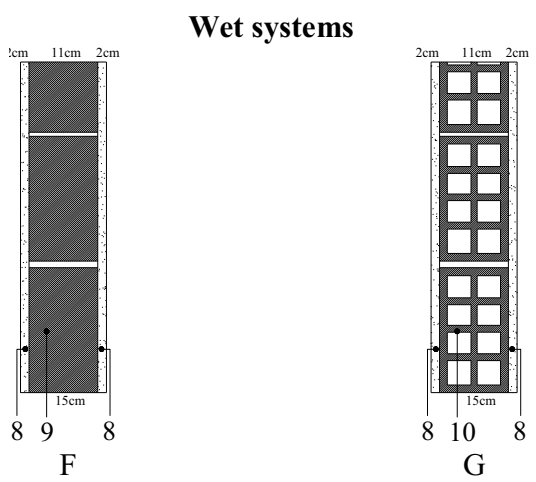

Figure 6. Transversal sections of wet interior partition wall systems analysed. Legend: 8. Mortar; 9. Ceramic solid brick; 10. Ceramic hollow brick.

The Embodied water is the amount of water used to manufacture materials. Water cost in the manufacture of goods and services required by construction may be significantly diverse depending to regional differences on water availability.

This study compares seven different partition walls commonly used in Mediterranean climates, five dry solutions and two wet solutions. Figure 5 presents the dry solutions: mat canes filled with reed (Figure 5A), timber frame filled with straw (Figure 5B), wattle and daub (Figure $5 \mathrm{C}$ ), wooden board with timber frame and rock wool insulation (Figure 5D), plasterboard partition wall with light steel frame structure and rock wool insulation (Figure 5E).

Dry solutions are lightweight, allowing a lower embodied energy and other more favourable environmental 
impact indicators. Compared to wet and heavyweight solutions, such as hollow brick and solid brick walls, dry and lightweight solutions allow also easier deconstruction/reuse scenarios.

The values presented on Table 3 are based on bibliographical references $[6,22,23]$. The functional unit selected was one square meter of solution.

Table 3. Environmental impacts of the dividing wall systems analysed.

\begin{tabular}{|c|c|c|c|c|c|c|c|}
\hline \multirow[b]{2}{*}{$\begin{array}{l}\text { Impact } \\
\text { categories }\end{array}$} & \multicolumn{5}{|c|}{ dry } & \multicolumn{2}{|c|}{ wet } \\
\hline & $\mathbf{A}$ & B & $\mathbf{C}$ & D & $\mathbf{E}$ & $\mathbf{F}$ & $\mathbf{G}$ \\
\hline Specific & & & & & & & \\
\hline $\begin{array}{l}\text { Weight } \\
\left(\mathrm{kg} / \mathrm{m}^{2}\right)\end{array}$ & 17,5 & 28,0 & 39,0 & 19,0 & 30,4 & 386 & 179 \\
\hline $\begin{array}{l}\mathrm{EW}^{\mathrm{a}} \\
\left(1 / \mathrm{m}^{2}\right)\end{array}$ & 31,4 & 83,7 & 146,7 & 114,6 & 56,6 & 793,4 & 330,0 \\
\hline $\begin{array}{l}\mathrm{EE}^{\mathrm{b}} \\
\mathrm{kWh} / \mathrm{m}^{2}\end{array}$ & 37 & 28 & 14 & 13 & 62 & 457 & 140 \\
\hline $\begin{array}{l}\overline{G W P}{ }^{c} \\
\left(\mathrm{~g} / \mathrm{m}^{2}\right)\end{array}$ & 971 & 2462 & 4182 & 2331 & 14387 & 69646 & 23218 \\
\hline $\begin{array}{l}\mathrm{AP}^{\mathrm{d}} \\
\left(\mathrm{g} / \mathrm{m}^{2}\right)\end{array}$ & 8 & 20 & 35 & 30 & 114 & 723 & 217 \\
\hline $\begin{array}{l}\mathrm{COD}^{\mathrm{e}} \\
\mathrm{POCP} \\
\left(\mathrm{g} / \mathrm{m}^{2}\right) \\
\end{array}$ & 105 & 214 & 229 & 28 & 2211 & 6325 & 2340 \\
\hline $\begin{array}{l}\text { Generated } \\
\text { Waste }^{\mathrm{f}} \\
\left(\mathrm{g} / \mathrm{m}^{2}\right) \\
\end{array}$ & 162 & 323 & 698 & 1012 & 2552 & 30725 & 6052 \\
\hline $\begin{array}{l}\mathrm{U} \text { value }{ }^{\mathrm{g}} \\
\mathrm{W} / \mathrm{m}^{2}{ }^{\circ} \mathrm{C}\end{array}$ & 0,6 & 0,7 & 1,4 & 0,6 & 0,7 & 2,3 & 1,8 \\
\hline $\begin{array}{l}{ }^{\mathrm{a}} \text { EW (Emb } \\
{ }^{\mathrm{b}} \text { EE (Emb } \\
{ }^{\mathrm{c}} \text { GWP (Gl } \\
{ }^{\mathrm{d}} \text { AP (Acid } \\
{ }^{\mathrm{e}} \text { COD (C) } \\
{ }^{\mathrm{O}} \text { Ozone Cre } \\
{ }^{\mathrm{f}} \text { Generatec } \\
{ }^{\mathrm{g}} \text { Coefficie }\end{array}$ & $\begin{array}{l}\text { oodied } \\
\text { odied } \\
\text { obal Y } \\
\text { ificatic } \\
\text { hemice } \\
\text { ation F } \\
\text { d waste } \\
\text { nt of H }\end{array}$ & $\begin{array}{l}\text { Water) } \\
\text { Energy) } \\
\text { Jarming } \\
\text { n Poter } \\
\text { l Oxys } \\
\text { otentia } \\
\text { in pro } \\
\text { leat Tra }\end{array}$ & $\begin{array}{l}\text { Potenti } \\
\text { tial) in } \\
\text { len Dep } \\
\text { l) in equ } \\
\text { duction } \\
\text { nsmissi }\end{array}$ & $\begin{array}{l}\text { in eq } \\
\text { uivale } \\
\text { tion) } \\
\text { alent } \\
\text { ocess; } \\
\text { [23]. }\end{array}$ & $\begin{array}{l}\text { livalent } \\
\mathrm{CO}_{2} \text { gr } \\
\text { nd } \mathrm{POC} \\
\mathrm{O}_{x} \text { gram }\end{array}$ & $\begin{array}{l}\text { ) grams; } \\
\text { ns; } \\
\text { (Photocl }\end{array}$ & emical \\
\hline
\end{tabular}

\section{Results and discussion}

The aim of this research was to investigate the water demand in the production of interior partition wall systems for building rehabilitation.

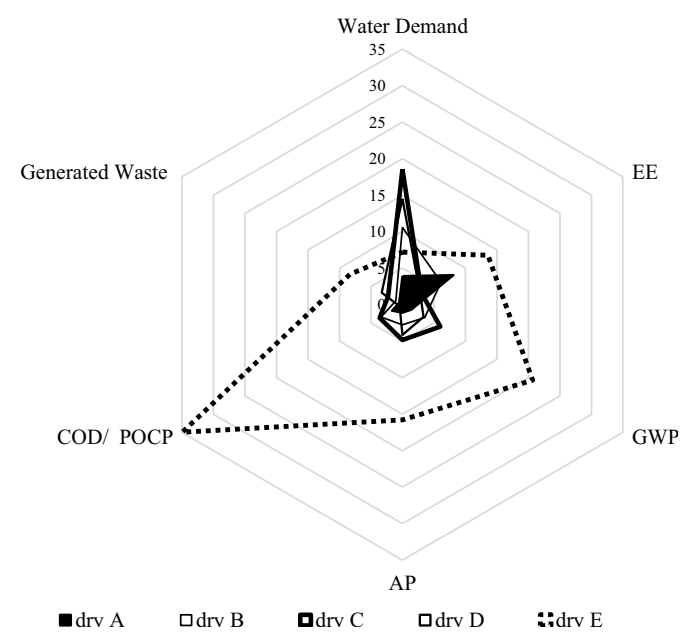

Figure 7. Comparison between dry partition wall systems analysed. The overall best solution presents the lower polygon area and the lower value for each indicator.
There is a considerable amount of water used in the materials production phase and in building construction phase. The highest values verified were for the wet and heavyweight systems.

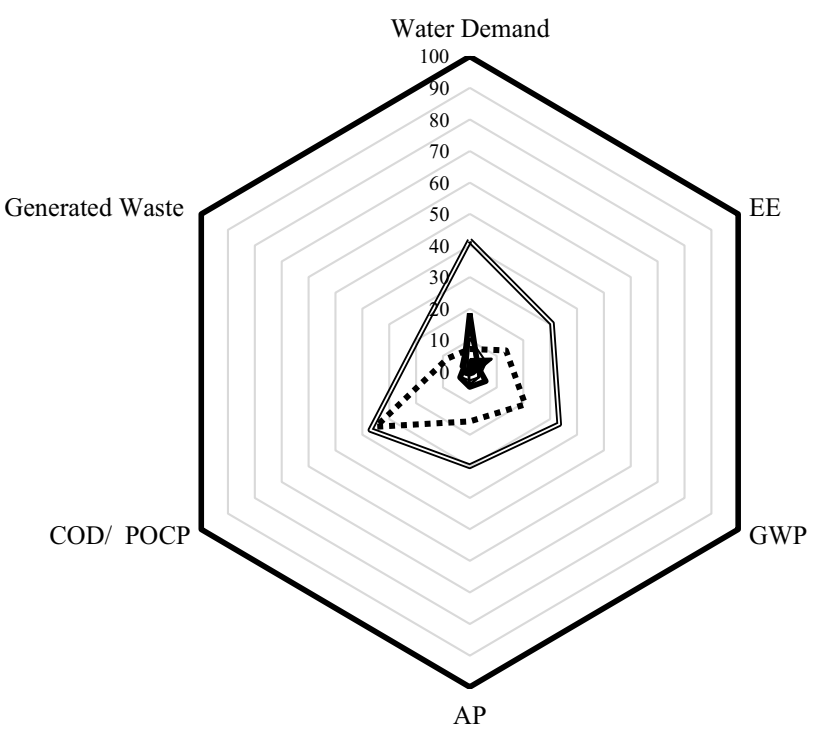

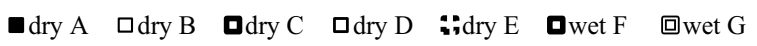

Figure 8. Comparison between all partition walls systems analysed. The worst solution presents the higher polygon area and the higher value for each indicator.

The highest value was 793.4 litres per square meter of gross floor area. These findings suggest that the selection of elements and materials has a great impact on a building's water demand during the construction phase. This research allows selecting the partition wall solutions that might be more sustainable in terms of water use.

The aim of the analysis was to provide multiple criteria for decision-making according to the values of different impact categories for several building materials.

From the results presented in Table 3, comparing the dry and the wet constructive systems, it is possible to conclude that the embodied water as well as other environmental impact indicators presents lower values in dry solutions. The worst solution in all indicators is the solution F. Between dry traditional Mediterranean solutions, like A B, C and D, the best solution is A except in EE indicator. However, solution D, wooden board with timber frame filled with rock wool, present the best values of $\mathrm{EE}$ and $\mathrm{COD} / \mathrm{POCP}$ indicators, but it presents the second worst level of Water Demand and Generated Waste, when compared with other dry systems. Analysing the Figure 7, it can be seen that solution with worst overall impact is solution $\mathrm{E}$ and the best is $\mathrm{A}$.

From the analysis of the solutions presented it can be concluded that to achieve a solution with low environmental impact levels it is necessary to reduce the quantity of materials used, especially those resulting from more industrialized and higher energy demanding production processes, with higher EE, such as light gauge steel frame or rock wool. For example, reed and cork present a significantly lower EE than Rockwool. 
The dry and mechanically detachable wall systems have a smaller impact on the building's environmental impact, while the on-site construction systems present a significantly higher impact.

Policy focused on reducing water consumption should consider the use of dry and lightweight systems.

\section{Conclusions}

Dry systems of interior partition walls are certainly a wiser option in many situations as these can be more flexible and even portable, in some cases. The lower quantity of materials used in these lightweight solutions allow lower water use as well as other more favourable environmental impact indicators.

The reduction of material inputs to the minimum is a way to achieve higher eco-efficiency in a building and thus open the way to the development of efficient interior partition systems. The need for more sustainable construction, using innovative solutions has also motivated this study and the development of materials and construction technologies using lightweight materials.

Efforts for reducing the construction industry water consumption need to be focused up and downstream of the actual construction process. However, the complexity of the supply chain makes it difficult to ascertain precisely where efforts should be focused. A demand-side view is required to solve the problem of scarce water supplies. The drivers of demand, both direct and indirect, need to be managed through all stages of production.

In conclusion, the buildings rehabilitation with dry and lightweight systems constitute an important contribute to sustainability. These systems allow buildings to be adaptable in order to remain updated within the contemporary framework of sustainability.

\section{Acknowledgments}

The first author wish to thank FCT (Fundação para a Ciência e Tecnologia - Portugal), MCE (Ministério da Educação e Ciência - Portugal) and ESF (European Social Fund) for supporting the research fellow with the reference SFRH/BD/104891/2014. The second author wish to thank the financial support from the Project UID/AUR/04509/2013 by FCTMEC by national funding and, when applicable, FEDER co-financing under the new PT2020 partnership agreement.

\section{References}

1. Euroconstruct. European construction: Market Trends to 2012 in 68th Euroconstruct conference. KOF and ETH, Zurich; November 26-27 (2009)

2. C. Richard and C. Schulz. Energy efficiency refurbishments: Principles, details, examples. Detail Green Books, Munich (2013)

3. C. Schittiich. Rehabilitation: Reconversion, Extensions, Reconversions. Edition Detail, Munich (2006)

4. F. Jürgen. Water use in industry. Eurostat Statistics in focus 14/2014 (2014)
5. S. Junnila and A. Horvath. Life-Cycle Environmental Effects of an Office Building. Journal of Infrastructure Systems, 157-166, (2003)

6. R. Mateus, S. Neiva, L. Bragança, P. Mendonça, and M. Macieira. Sustainability assessment of an innovative lightweight building technology for partition walls comparison with conventional technologies. International Journal Building and Environment. doi:10.1016/j.buildenv.2013.05.012. (2013)

7. P. Mendonça and M. Macieira. ADjustMEMBRANE: Innovative Lightweight Adjustable Partition Wall System. International Journal of Architectonic, Spatial, and Environmental Design. 7, 2, 39-50 (2013)

8. A. Friedman. The Adaptable House: Designing Homes for Change. McGraw Hill Professional, (2002)

9. K. Tichelmann and J. Pfau. Dry Construction Principles: details and examples. Edition Detail, Munich, 7-9 (2007)

10. L. Bragança, R. Mateus and H. Koukkari. Building Sustainability Assessment. Sustainability. Vol. 2(7), July, p2010-2023 (2010)

11. W. Addis and J. Schouten. Principles of design for deconstruction to facilitate reuse and recycling. CIRIA, London, 38, 39 (2004)

12. H. König et al. A life cycle approach to buildings Principles, calculations and design tools. Detail Green books, Munich, 66 (2011).

13. EPA (Environmental Protection Agency), SBA (Science Advisory Board). Reducing Risk: Setting Priorities and Strategies for Environmental Protection, EPA, Washington, DC, United States, SAB-EC-90-021, (2000), pp. 13-14.

14. T. Graham, M. McCormack, L. Palmowski, and R. Fay. Embodied water of construction. Royal Australian Institute of Architects, BEDP Environment Design Guide, 58, 1-8 (2011)

15. S. Vassig, E. Ozer and T. Spiegelhalter. Best practices in Sustainable Building Design. J. Ross publishing (2011)

16. B. Berge. The Ecology of Building Materials. Architectural Press, Bath (1999)

17. I. Bribián, A. Capilla, A. Usón. Life cycle assessment of building materials: Comparative analysis of energy and environmental impacts and evaluation of the ecoefficiency improvement potential, Building and Environment 46, 1133-1140 (2011)

18. ASTM International.. CFFA SPPR PVC Membrane EPD, United States (2013)

19. M. Macieira. Architectural membranes: potential application in the interior of buildings. Dissertation for Master degree in Architecture. University of Minho, Portugal (2012)

20. P. Mendonça and M. Macieira. Interior partition walls in Mediterranean climates - lightweight versus heavyweight. International Conference "Sustainable Environment in the Mediterranean Region: from Housing to Urban and Land Scale Construction", Naples, Italy (2012)

21. F. Pinho. Paredes de Edificios Antigos em Portugal (in Portuguese), 2nd edition, LNEC, Lisbon (2000)

22. P. Mendonça. Living under a second skin - Strategies for Environmental Impact Reduction for Solar Passive 
Constructions in Temperate Climates. Doctorate Thesis in Civil Engineering, University of Minho, Portugal (2005)
23. C. Santos and L. Matias. Coeficientes de transmissão térmica de elementos da envolvente dos edifícios (in Portuguese), IT

24. E50, LNEC, Lisbon, 43-50 (2007) 